\title{
Potential use of electrical penetration graph (EPG) technology for biosecurity incursion response decision making
}

\author{
W.R.M. Sandanayaka ${ }^{1}$, J.G. Charles ${ }^{1}$ and K.J. Froud ${ }^{2}$ \\ ${ }^{1}$ The New Zealand Institute for Plant \& Food Research Limited, Private Bag 92169, Auckland \\ Mail Centre, Auckland 1142, New Zealand \\ ${ }^{2}$ Biosecurity Research Limited, Mt Eden, Auckland, New Zealand \\ Corresponding author: Manoharie.Sandanayaka@plantandfood.co.nz
}

\begin{abstract}
Sap-sucking insects pose a significant biosecurity risk as they can cause direct damage to plants and may also vector serious plant pathogens. However, there is a paucity of tools for rapidly estimating the host range of such insects during a biosecurity incursion. The Electrical Penetration Graph (EPG) technique has been developed over the past 50 years for analysing, quantifying, and comparing the feeding behaviours of both phloem and xylem sap-sucking insects. Electrically generated waveforms associated with insects' probing and feeding behaviours may allow a rapid assessment of the potential host range of invading sap sucking insects. This paper reviews the development and use of EPG, assesses potential for host-range testing of recent incursions, analyses when and how the EPG tool could be applied for response, and identifies seven points where EPG could aid biosecurity incursion response decision making. Three recent biosecurity responses could have benefited from EPG.
\end{abstract}

Keywords Host plant, host range, Electrical Penetration Graph technology, Biosecurity Response Knowledge Base, BRKB.

\section{INTRODUCTION}

Biosecurity agencies must rapidly assess the risk posed by invasive, phytophagous insects when they are first discovered in a new area or country. In New Zealand, the Ministry for Primary Industries (MPI) is responsible for the investigation and risk assessment of new incursions (Froud \& Bullians 2010). The MPI then works in partnership with potentially affected industries to decide on response actions, which include eradication, long-term management or no action. An important aspect of this process is assessment of potential host plants of the new insect (Burnip \& Froud 2008; Burckhardt et al. 2014). There is a paucity of tools for rapidly estimating the host-range of hemipterans, commonly referred to as sucking insects (Martin 2008; Burckhardt et al. 2014). Hemipterans pose a significant biosecurity risk as they can cause direct damage to plants and may also vector serious plant pathogens (Nault 1997; Madden et al. 2000). The mouthparts of Hemiptera have been adapted for piercing and sucking host plant tissues. The mandibles and maxillae are modified as needle-like stylets. The stylet bundle consists 
of two canals: one for secreting saliva and one for sucking sap out of the plant tissues. The stylet pathways in plant tissues can be intracellular, intercellular or a mixture of both and varies among insect groups depending on whether they are xylem or phloem feeders (Spiller et al. 1985; Tjallingii \& Hogen Esch 1993).

The Electrical Penetration Graph (EPG) techniquehas been developed over the past 50 years and is now a vital tool for analysing, quantifying, and comparing the feeding behaviours of both phloem and xylem sap-sucking insects. There is potential for EPG to determine host-plant associations during biosecurity incursions to assess the environmental threat of an organism, identify which industries may be affected and to support response actions (Sandanayaka et al. 2013). However, to date, EPG has not been considered for host-plant determination for biosecurity incursions.

The host range of invasive insects may be already known from the international literature. However, when this is not available, host plants must be inferred by the plants the invasive insect was detected on or estimated from knowledge of related insects. Traditionally, the host range of poorly understood invasive insects has been ascertained by experimental assays. These assays expose insects to selected plants, quantify the extent of feeding and assess the physiological development and reproduction of the insect (Withers et al. 2011).

The objective of this paper is to explore the potential use of EPG for biosecurity risk assessment and response decisions. This was achieved, firstly, by undertaking a literature review of the technique and describing the process for its application and, secondly, by describing the key decision points in biosecurity risk assessment and response where the tool could be applied. An assessment of how EPG could have been utilised for recent insect incursions in New Zealand is made.

\section{METHODS}

\section{Literature review}

A literature survey was conducted to assess the utility of EPG to rapidly identify host-plant associations of invasive sap-sucking insects.

\section{Assessment of biosecurity decision points for EPG} Key decision points in biosecurity risk assessment and response where the tool could be applied were identified by searching the MPI online biosecurity response knowledge base (BRKB) (Ministry for Primary Industries 2010). The $\mathrm{BRKB}$ gives the policy for responding to risk organisms and details the processes, procedures and tools for biosecurity responses. Examples of how EPG could be used for each decision point were developed based on the BRKB guidelines. A flow diagram of the possible process for using EPG in a biosecurity response was developed based on the literature review and assessment of biosecurity decision points.

\section{Case studies for EPG}

A list of all insect responses in the last 10 years was provided by the MPI collated from their response database and from the risk analysis database. Each organism was assessed to determine whether there was evidence of EPG use in species in the same taxonomic family, which would indicate if EPG may have been suitable for the risk organism.

\section{RESULTS}

\section{Literature review}

Key papers relating to how EPG may be applied to biosecurity incursions were identified and summarised from 416 papers found from literature on insect feeding monitor and EPG between 1964 and 2016.

\section{Hemiptera host-plant assessment}

Host-plant acceptance by Hemiptera can be assessed in terms of food ingestion and/or reproduction (Powell et al. 2006). Before EPG, host selection and acceptance by sucking insects were measured by observations of the initial behaviour of an insect after alighting on a plant surface (i.e. duration of the first walk or proboscis contact period (Tjallingii 1976)). However, aphids (and probably most Hemiptera) do not show clear discrimination between host and 
non-host plants until they have inserted their stylets (Powell et al. 2006) so initial alighting observations are not useful.

Host acceptance by sucking insects has been assessed by visually observing the behaviour of insects on selected plant species or quantifying their excretory droplets (Pathak et al. 1982). These methods are time consuming and also honeydew secretion could be partially controlled by environmental factors influencing the insect and its host (Dungan \& Kelly 2003) so it is not a reliable method.

\section{Electrical Penetration Graph (EPG) technique}

The EPG technique was developed over 50 years ago and has been modified in a number of ways since then (McLean \& Kinsey 1964; Tjallingii 1978; Backus \& Bennett 2009). An EPG system consists of a monitor with two electronic components, a voltage source and an input resister that are electrically connected to each other. A wire from the input of the monitor is attached to the insect using a special glue containing silver to make it conductive. A conductive object, such as a thick copper wire, from the output of monitor (plant electrode) is inserted into the plant tissue or the potting soil in which the plant is rooted. The EPG thus 'electrifies' the plant and measures changes in electrical resistance when an insect's stylets probe different parts of a plant as part of an electric circuit. Fluctuations in voltage are caused by stylet penetration and positioning activities within the plant tissues (Tjallingii \& Hogen Esch 1993), which change the electrical resistance over time, and are recorded as waveforms. The occurrence, sequence and duration of each stylet penetration event (such as time until the first probe, total probing time, duration of feeding (either phloem or xylem) and sustained ingestion) can be interpreted using various wavelength parameters (Prado \& Tjallingii 1997).

Waveform correlations obtained from EPG have been used successfully to study feeding behaviour of many species from many groups of insects, including phloem feeders and a few xylem feeders (Table 1). The EPG technique has shown that the stylet of a phloem sap feeding insect may briefly puncture cells in all tissues when it probes into a plant. However, the final decision on hostplant acceptance (i.e. feeding) is not made until the stylet enters the phloem or xylem (Sandanayaka \& Backus 2008; Sandanayaka et al. 2013). The phloem cell is usually punctured toward the end of each probe. In non-host plants, stylet withdrawal from the phloem cell occurs rapidly, typically within three seconds, followed by stylet withdrawal from the plant (Powell et al. 2006).

\section{Use of the EPG technique for host-range determination}

The first EPG study on host range was reported by (McLean \& Kinsey 1968) who compared probing behaviours of the pea aphid, Acyrthosiphon pisum on known host and non-host plants. Since then, the EPG technique has been applied to test host plant acceptance by many hemipterans (Table 1). Insects on hosts tend to have shorter salivation and longer ingestion periods. Insects on nonhost plants typically have shorter first probes, longer pathway probing, longer non-probing periods and delayed or no phloem finding and subsequent ingestion (Calatayud et al. 1994; Lei et al. 1999; Liu \& Takahashi 2000).

Holbrook (1980) screened 25 Solanum cultivars and one suspected non-host (Pelargonium cultivar) for acceptability to the green peach aphid Myzus persicae. The number of probes and the time spent in probing were indicators of relative acceptability in a 15-30 min recording period, and an "acceptability index" was worked out on the basis of those two EPG measurements on the test plant and the control plant. Girma et al. (1994) calculated a Potential Phloem Ingestion Index $(\mathrm{PPII}=(\mathrm{PI} / \mathrm{PPI}) \times 100)$ of Russian wheat aphid Diuraphis noxia on a range of plants. In that equation, PI is total time of ingestion from the phloem and PPI is the potential phloem ingestion or total recording time minus the time taken to perform the first committed phloem ingestion ( $>15$ min ingestion). The PPII was found to be high in host plants and low in non-host plants. Tjallingii (1995) also reported that carefully selected EPG parameters could be used to identify the location of stylets in plant tissues to study the 
Table 1 Examples of Electrical Penetration Graph (EPG) use across a range of hemipteran families and the EPG recording times used in host plant acceptance studies.

\begin{tabular}{|c|c|c|c|}
\hline Insect family & Insect species & $\begin{array}{l}\text { EPG recording } \\
\text { period }^{\text {a }}(\mathrm{h})\end{array}$ & Reference \\
\hline \multirow[t]{6}{*}{ Aphidae } & Schizaphis graminum & 3 & Zúñiga et al. 1988 \\
\hline & Rhopalosiphum padi & 3 & Zúñiga et al. 1988 \\
\hline & Rhopalosiphum padi & 8 & Prado \& Tjallingii 1997 \\
\hline & Diuraphis noxia & 12 & Girma et al. 1992 \\
\hline & Myzus persicae & 10 & Cole 1997 \\
\hline & Aphis fabae & 8 & Prado \& Tjallingii 1997 \\
\hline Aphrophoridae & Carystoterpa fingens & $8-12$ & $\begin{array}{l}\text { Sandanayaka \& Page-Weir 2009; } \\
\text { Sandanayaka et al. } 2013\end{array}$ \\
\hline Aleyrodoidae & Bemisia tabaci & 6 & Liu et al. 2012 \\
\hline \multirow[t]{5}{*}{ Cicadellidae } & Empoasca fabae & 2 & Backus \& Hunter 1989 \\
\hline & Nephotettix virescens & 8 & Liu \& Takahashi 2000 \\
\hline & Empoasca vitis & 5 & Jin \& Baoyu 2007 \\
\hline & Homalodisca vitripennis & 20 & Sandanayaka \& Backus 2008 \\
\hline & Orosius orientalis & 8 & Trebicki et al. 2012 \\
\hline Coreidae & Anasa tristis & 8 & Bonjour et al. 1991 \\
\hline Delphacidae & Nilaparvata lugens & 4 & Hattori 2001 \\
\hline Miridae & Lygus hesperus & 2 & Backus et al. 2007 \\
\hline \multirow[t]{2}{*}{ Pseudococcidae } & Phenacoccus manihoti & 12 & Calatayud et al. 1994 \\
\hline & Planococcus citri & 16 & Costa Santa-Cecilia et al. 2013 \\
\hline Psyllidae & Psylla pyricola & 7 & Ullman \& McLean 1988 \\
\hline Triozidae & Bactericera cockerelli & 12 & Sandanayaka et al. 2014 \\
\hline
\end{tabular}

a The EPG recording period is defined as the total duration (h) that the insect was monitored for feeding.

plant factors responsible for host acceptance.

Similarities in EPG waveforms from many species have allowed a standardised labelling system to be developed that represents key stylet penetration activities, such as intracellular punctures, phloem salivation and phloem ingestion (Reese et al. 2000). The standard labelling system has allowed EPG to reveal comparative differences in feeding behaviour shown by insects when feeding on different host plants and could be applied to ascertaining the host range of hemipterans in biosecurity responses (Sandanayaka et al. 2013). Therefore, these authors proposed that EPG may allow a rapid assessment of the potential host range of invading sapsucking insects.

\section{Using the EPG technique for biosecurity response decision making}

Successful operation of an EPG requires a degree of skill and experience as does interpretation of the output data (the waveforms generated by monitoring the feeding behaviour of the insects). However, this equipment is relatively cheap to operate in comparison with setting up alternative infrastructure for host-plant testing of chewing insects (Suckling et al. 2014). For use in a biosecurity response, the stylet penetration of 
eight insects could be monitored simultaneously using a Giga-8 DC-EPG system (WF Tjallingii, Wageningen, The Netherlands). The data from the EPG monitor are acquired and stored using Stylet $+\mathrm{d}$ software (EPG Systems, Wageningen, The Netherlands). Faraday cages are used in all cases to reduce electrical interference. Despite the extensive literature on the EPG technique, there are no examples where host plant assessment has been undertaken using EPG during a biosecurity incursion. In New Zealand, EPG was applied following a biosecurity response for host plant assessment of Bactericera cockerelli (Tomato potato psyllid) but only after the decision was made not to eradicate this organism and the horticultural industry began long-term management of this new species (Sandanayaka et al. 2011).

A flow diagram of how the EPG technique would be applied during biosecurity responses is given in Figure 1. The use of EPG can be very flexible depending on the host range under examination. For example, a comparison test between a known host plant, and the suspect host can be conducted with as little as two insects within a 2-day period for a single host that an industry has concerns about (W.R.M. Sandanayaka, unpublished data). Ideally, replicates of 10 insects per host plant would be used to increase the confidence in the results (Sandanayaka et al. 2013). The one EPG unit currently available at Plant \& Food Research, New Zealand enables 10 replicates of up to eight host plants to be screened over a 10-day period. Access to additional EPG units could be arranged within two weeks at a current (May 2017) cost of 4250 EUR ( $\$ 6450$ NZD) per Giga-8 DC-EPG monitor (EPG Systems EU). In addition, the cost for gold wire and conductive silver paint consumables will be around 200 EUR (\$303 NZD).

A thorough understanding of "time to first probe", "duration of first probe" "total probing time" "time to first phloem /xylem ingestion from the beginning of the recordings", "time to phloem /xylem ingestion from the beginning of that probe", "total duration of phloem/ xylem ingestion" and "Potential Phloem/
Xylem Ingestion Index" in relation to the stylet penetration activities of an insect is necessary to assess host plant acceptance. For example, the information in Table 1 indicates that sufficient data to differentiate host and non-host plants can be obtained within a 3-hour recording period for some aphid species (Zúñiga et al. 1988). However, between 8 and $12 \mathrm{~h}$ of recording is required to demonstrate feeding in most tested aphid species (Girma et al. 1992; Cole 1997; Prado \& Tjallingii 1997). Mealybugs spend a long time probing before starting phloem ingestion so a $12-16 \mathrm{~h}$ recording period is required to assess feeding for these species (Table 1). Of note, is that a recording periods range from $2-20 \mathrm{~h}$ for several Cicadellidae species were required to demonstrate adequate feeding. Therefore several preliminary tests may be required to determine the optimal recording period for species in this family. The information in Table 1 can be applied as an initial recording period for host testing as part of a biosecurity response. However, a minimum 10-hour recording period on a known host should be used to determine the optimal recording period of a novel insect species under a biosecurity incursion. The initial recordings will show the time to the first phloem or xylem ingestion. Plant acceptance will indicated by "time to first sustained phloem ingestion/xylem ingestion (>10 min ingestion)", "total duration of phloem/xylem ingestion" and "Potential Phloem/Xylem Ingestion Index" (Sandanayaka \& Backus 2008). Recording these EPG parameters for a known host will assist with determining the required recording period for the particular insect species on a range of potential host plants (known and unknown). Previous studies using EPG have shown that insects on non-host plants typically have shorter first probes, longer pathway probing, longer non-probing periods, and no, or reduced, feeding (by withdrawing stylets from the phloem/xylem cells) than on host plants (Sandanayaka et al. 2013). Therefore, these parameters can be used to determine the EPG test outcomes of host, suspected host and non-host in a biosecurity response. 
Figure 1 Process diagram of the use of EPG within a biosecurity incursion response.

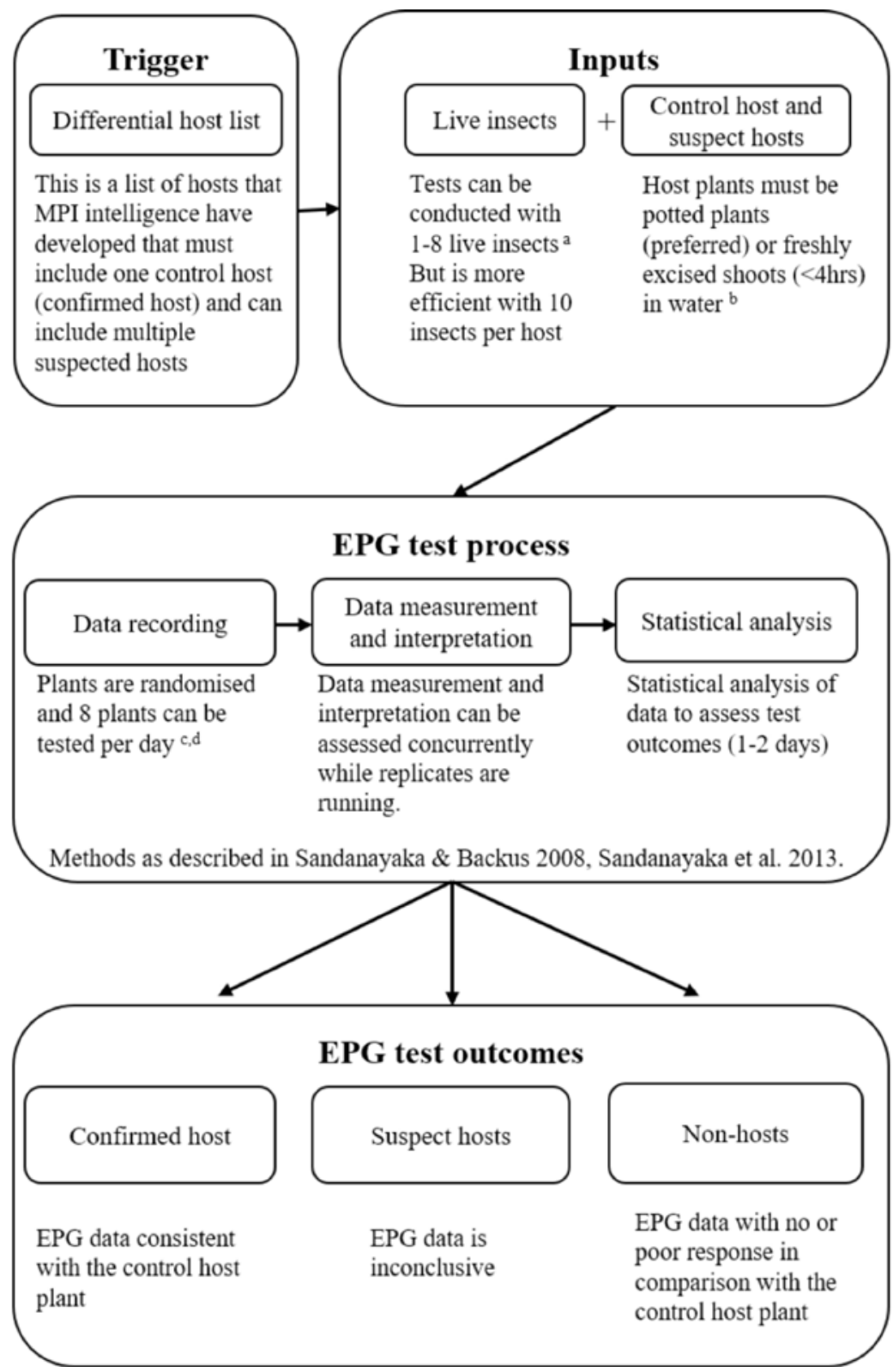

${ }^{a}$ Adults are the preferred live stage for testing as they are more robust; however, for some larger hemipteran insects immature life stages could be used. ${ }^{\mathrm{b}}$ Shoots must be kept fresh during the experiment to avoid blockage of the sieve elements, which could affect feeding. ${ }^{c}$ Changes from an initial recording period of 10 hours would be decided based on recommendations in Table 1 for specific species or families. ${ }^{\mathrm{d}}$ The Giga 8 EPG-DC monitor has eight channels so can monitor eight insects on eight plants for each recording period but more units could be used. 


\section{Using EPG as a tool to assist biosecurity decision making}

There are several key decision points in a biosecurity incursion response (Ministry for Primary Industries 2011a). The first stage of a response is the Investigation Phase. In this phase, the risk is assessed to determine if an incursion has occurred, and a rapid risk assessment is made to determine if a response is required (Froud \& Bullians 2010; Ministry for Primary Industries 2014). Biosecurity response decisions are, as of 1 July 2017, made in partnership with affected industries where a Government Industry Agreement exists.
A search of the Ministry for Primary Industries BRKB (Ministry for Primary Industries 2011a) found seven decision points where EPG may be able to assist with decision making in a biosecurity incursion, and examples of use are given in Table 2. Under existing response systems, a differential host range list (Figure 1) would be developed by the intelligence team as part of an organism science report. Such lists are compiled using data from literature reviews, risk analysis reports, scientific experts and technical advisory groups (Ministry for Primary Industries 2011b, 2012a).

Table 2 Biosecurity decision points where there is potential to assist decision making by using the EPG technique to understand the host range of hemipteran incursions.

\begin{tabular}{|c|c|c|c|c|}
\hline $\begin{array}{l}\text { Biosecurity } \\
\text { Response } \\
\text { phase }\end{array}$ & Decision point & Reference & $\begin{array}{l}\text { Potential } \\
\text { for EPG } \\
\text { to inform } \\
\text { decision? }\end{array}$ & Example of use \\
\hline $\begin{array}{l}\text { Investiga- } \\
\text { tion }\end{array}$ & $\begin{array}{l}\text { Does a biosecurity risk } \\
\text { remain? }\end{array}$ & $\begin{array}{l}\text { Ministry } \\
\text { for Primary } \\
\text { Industries } \\
(2013 a)\end{array}$ & Yes & $\begin{array}{l}\text { EPG use to ascertain risk } \\
\text { organism threat to economic } \\
\text { or environmental values where } \\
\text { significant uncertainty exists } \\
\text { around the host range. One } \\
\text { confirmed host must be known. }\end{array}$ \\
\hline $\begin{array}{l}\text { Investiga- } \\
\text { tion }\end{array}$ & $\begin{array}{l}\text { Determine if response } \\
\text { recommended? }\end{array}$ & $\begin{array}{l}\text { Ministry } \\
\text { for Primary } \\
\text { Industries } \\
(2012 \mathrm{~b})\end{array}$ & No & $\begin{array}{l}\text { Decision agreed between Incursion } \\
\text { Investigation and Response teams. } \\
\text { Unknown host range may initiate a } \\
\text { response. }\end{array}$ \\
\hline $\begin{array}{l}\text { Transition } \\
\text { to } \\
\text { Response } \\
\text { Phase }\end{array}$ & $\begin{array}{l}\text { Under the Government } \\
\text { Industry Agreements } \\
\text { (GIA) partnership } \\
\text { programme, who } \\
\text { should be involved in a } \\
\text { decision to respond? }\end{array}$ & $\begin{array}{l}\text { Pascoe } \\
(2016)\end{array}$ & Yes & $\begin{array}{l}\text { Under GIA, affected industries } \\
\text { become involved in decision } \\
\text { making and funding a response. } \\
\text { EPG use can determine which } \\
\text { industries will be affected. }\end{array}$ \\
\hline $\begin{array}{l}\text { Response } \\
\text { Phase }\end{array}$ & $\begin{array}{l}\text { What is the host range? } \\
\text { (Organism science } \\
\text { report) }\end{array}$ & $\begin{array}{l}\text { Ministry } \\
\text { for Primary } \\
\text { Industries } \\
(2012 a)\end{array}$ & No & $\begin{array}{l}\text { Information on the known and } \\
\text { suspected host range. Used to } \\
\text { inform the differential host plant } \\
\text { list for an EPG project. }\end{array}$ \\
\hline
\end{tabular}




\begin{tabular}{|c|c|c|c|c|}
\hline $\begin{array}{l}\text { Response } \\
\text { phase }\end{array}$ & $\begin{array}{l}\text { What is the host range? } \\
\text { (Science and Research } \\
\text { project) }\end{array}$ & $\begin{array}{l}\text { Ministry } \\
\text { for Primary } \\
\text { Industries } \\
(2011 \mathrm{c})\end{array}$ & Yes & $\begin{array}{l}\text { Where host range is unknown } \\
\text { or ambiguous, Intelligence team } \\
\text { will request a research project. } \\
\text { EPG would clarify host range for } \\
\text { operational plan development } \\
\text { (for surveillance, tracing, } \\
\text { movement control and organism } \\
\text { management). }\end{array}$ \\
\hline $\begin{array}{l}\text { Response } \\
\text { phase }\end{array}$ & $\begin{array}{l}\text { What is the host range } \\
\text { for movement control? }\end{array}$ & $\begin{array}{l}\text { Ministry } \\
\text { for Primary } \\
\text { Industries } \\
(2013 \mathrm{~b})\end{array}$ & Yes & $\begin{array}{l}\text { EPG informs hosts in the } \\
\text { movement control operational } \\
\text { plans to prohibit movement within } \\
\text { the incursion zone. }\end{array}$ \\
\hline $\begin{array}{l}\text { Response } \\
\text { phase }\end{array}$ & $\begin{array}{l}\text { What is the host range } \\
\text { for surveillance and } \\
\text { tracing? }\end{array}$ & $\begin{array}{l}\text { Ministry } \\
\text { for Primary } \\
\text { Industries } \\
(2013 \mathrm{c})\end{array}$ & Yes & $\begin{array}{l}\text { EPG informs hosts for the } \\
\text { surveillance and tracing } \\
\text { operational plan to target } \\
\text { surveillance and identify } \\
\text { movements of host plants for } \\
\text { forward and backward tracing and } \\
\text { surveillance visits. }\end{array}$ \\
\hline $\begin{array}{l}\text { Response } \\
\text { phase }\end{array}$ & $\begin{array}{l}\text { What is the host } \\
\text { range for organism } \\
\text { management? }\end{array}$ & $\begin{array}{l}\text { Ministry } \\
\text { for Primary } \\
\text { Industries } \\
(2012 \mathrm{c})\end{array}$ & Yes & $\begin{array}{l}\text { EPG informs hosts for the } \\
\text { organism management operational } \\
\text { plan to target eradication actions. }\end{array}$ \\
\hline $\begin{array}{l}\text { Response } \\
\text { phase }\end{array}$ & $\begin{array}{l}\text { How does the host } \\
\text { range affect the } \\
\text { costs and benefits } \\
\text { of response options } \\
\text { for eradication or no } \\
\text { action? }\end{array}$ & $\begin{array}{l}\text { Ministry } \\
\text { for Primary } \\
\text { Industries } \\
\text { (2011d); } \\
\text { Ministry of } \\
\text { Agriculture } \\
\text { and } \\
\text { Forestry } \\
(2003)\end{array}$ & Yes & $\begin{array}{l}\text { EPG informs the assessment of } \\
\text { response options. Host range } \\
\text { information enables policy advisors } \\
\text { to develop cost benefit analyses } \\
\text { for decisions on eradication, no } \\
\text { further action or transition to } \\
\text { long-term management. }\end{array}$ \\
\hline
\end{tabular}

\section{Case studies for EPG}

Details for 19 biosecurity incursions of hemipteran insects, detected in New Zealand for the first time between 2006 and 2016, were provided by the MPI. (Table 3 ). Of these, four have not established in New Zealand and the remaining 15 have established (Table 3). Of these 19 species, evidence of use of the EPG technique within the same taxonomic family exists for 14 (74\%) of them. 
Table 3 Summary of biosecurity incursions of Hemiptera insects, detected in New Zealand for the first time between 2006 and 2016 (Berry and Gill, pers. comm.) including establishment status and whether EPG has proven effective for use in members of the same taxonomic family.

\begin{tabular}{|c|c|c|c|c|c|}
\hline Scientific Name & $\begin{array}{l}\text { Common name } \\
\text { if given }\end{array}$ & Family & Year & Establishment & $\begin{array}{l}\text { EPG used } \\
\text { in family }\end{array}$ \\
\hline Bactericera cockerelli & $\begin{array}{l}\text { Tomato potato } \\
\text { psyllid }\end{array}$ & Psyllidae & 2006 & Yes & Yes \\
\hline $\begin{array}{l}\text { Bemisia tabaci } \\
\text { (Biotype Q) }\end{array}$ & $\begin{array}{l}\text { Sweet potato } \\
\text { white fly }\end{array}$ & Aleyrodidae & 2006 & Yes & Yes \\
\hline Planococcus citri & $\begin{array}{l}\text { Citrus } \\
\text { mealybug }\end{array}$ & Pseudococcidae & 2007 & Yes & Yes \\
\hline Rhopalosiphum sp. & - & Aphididae & 2008 & Yes & Yes \\
\hline Rhopalomyzus sp. & - & Aphididae & 2008 & No & Yes \\
\hline Antonina socialis & $\begin{array}{l}\text { Cottony } \\
\text { bamboo } \\
\text { mealybug }\end{array}$ & Pseudococcidae & 2008 & No & Yes \\
\hline Carulaspis minima & $\begin{array}{l}\text { Bermuda cedar } \\
\text { scale }\end{array}$ & Diaspididae & 2009 & Yes & No \\
\hline Melanaphis sp. & - & Aphididae & 2010 & No & Yes \\
\hline Illinoia lambersi & $\begin{array}{l}\text { Rhododendron } \\
\text { aphid }\end{array}$ & Aphididae & 2010 & Yes & Yes \\
\hline Acizzia solanicola & - & Psyllidae & 2012 & Yes & Yes \\
\hline $\begin{array}{l}\text { Thaumastocoris } \\
\text { peregrinus }\end{array}$ & Bronze bug & Thaumastocoridae & 2012 & Yes & No \\
\hline Neopinnaspis harperi & Harper scale & Diaspididae & 2012 & Yes & No \\
\hline Tuberolachnus salignus & $\begin{array}{l}\text { Giant willow } \\
\text { aphid }\end{array}$ & Aphididae & 2014 & Yes & Yes \\
\hline Myzocallis punctata & Oak aphid & Aphididae & 2014 & Yes & Yes \\
\hline Phellopsylla formicosa & $\begin{array}{l}\text { Psyllid on } \\
\text { eucalyptus }\end{array}$ & Psyllidae & 2014 & Yes & Yes \\
\hline Erthesina fullo & $\begin{array}{l}\text { Yellow spotted } \\
\text { stink bug }\end{array}$ & Pentatomidae & 2014 & No & Yes \\
\hline Eucalymnatus tessellatus & $\begin{array}{l}\text { Tessellated } \\
\text { scale }\end{array}$ & Coccidae & 2015 & Yes & No \\
\hline $\begin{array}{l}\text { Chrysomphalus sp. cf. } \\
\text { pinnulifer }\end{array}$ & - & Diaspididae & 2015 & Yes & No \\
\hline Charagochilus sp. & - & Miridae & 2016 & Yes & Yes \\
\hline
\end{tabular}




\section{DISCUSSION}

Assessment of the MPI biosecurity response knowledge base showed that the EPG technique could be used to inform response decisions at seven separate points. A key point early in a response is to use EPG to identify hosts that are important to specific industry groups. The EPG technique could also be used to identify hosts as part of the development of surveillance, tracing, movement control and organism management operational plans. In addition, the knowledge of which hosts may be affected (hosts and suspect hosts) is important in the development of a cost-benefit analysis of response options for eradication decisions. These points are supported by Burnip and Froud (2008) who showed that $33 \%$ of science inputs requested by the MPI were related to host information required to support the development of operational plans and assist containment and eradication options.

Over the last 10 years there have been 19 incursions of hemipteran insects in New Zealand (Table 3). Several of these have since become important economically damaging pests, e.g. (Bactericera cockerelli (tomato potato psyllid) (Teulon et al. 2009) and Tuberolachnus salignus (giant willow aphid) (Sopow et al. 2017) or minor pests Acizzia solanicola (Ministry for Primary Industries 2012d). The current review has identified literature relating to the efficacy of EPG in related insect species (Table 3) and indicated that EPG would have been suitable for use on $74 \%$ of these families. Every incursion is different and host range is just one of many factors that influences an eradication decision. However, with an average of two new incursions of sucking insects per year, it is likely that EPG could provide host range information to inform future response and eradication decisions in some species. The value of EPG to biosecurity authorities in the immediate aftermath of an incursion depends very much on the species, the extent to which its hosts are already known from overseas studies, and, perhaps, the feasibility of an eradication response.

To date, responses to incursions from sucking insect species have not benefited from host range information derived from using EPG.
However, the results of this study highlight the potential of, and describe the process for, use of EPG in future incursion events to assist in specific response decisions. There is evidence of EPG being used within the same taxonomic family as the three hemipteran incursions that have become important in New Zealand in the last decade. The EPG technique has subsequently been used to assess the host range and the vector ecology of one of these, the tomato potato psyllid (Sandanayaka et al. 2011). The giant willow aphid has been recorded on apples and pears in addition to willow (Sopow et al. 2017), and EPG could have usefully been used to determine if these important crops are feeding or shelter hosts. Similarly, the MPI requested solanaceous crop growers to report on the host range of Acizzia solanicola to inform their response (Ministry for Primary Industries 2012d) but EPG could have usefully been used to determine the host range.

The development of EPG over the past 50 years has resulted in a highly sensitive technique that can rapidly elucidate and quantify the feeding behaviours of sap-sucking insects. It is effective for both phloem and xylem feeders, and has been used to quantify and compare the responses of many different insects to a broad range of known host and known non-host plants. The EPG technique distinguishes between feeding behaviours that lead to acceptance or non-acceptance of a plant species based on the different durations of EPG waveforms for hosts and non-hosts. Waveform characteristics and interpretations have been validated across more than 10 different hemipteran families.

Limited examples of the optimal measurement period for some hemipteran families exist in the literature and there was variability in stylet penetration activities between species in the same family (Sandanayaka \& Hale 2003). However, the optimal period of EPG recordings can be informed by initial tests on a known host plant over 1 to 2 days if prior knowledge of the insect and the test plant are not available. Ten hours initial recording period is recommended for testing any novel insect species on EPG (W.R.M. Sandanayaka et al. unpublished data). 
An important limitation for use of EPG is that 'host acceptance' or 'host-rejection' by sucking insects may not be absolute. In nature, there may be a continuum between a 'host' and a 'non-host' that encompasses both 'good' and 'poor' hosts. In addition, a 'good' host species may become a 'poor' one (or even a non-host) within the course of a season as plant chemical defences, nutrition or environmental factors change.

In biosecurity incursions, decisions on host range are often targeted at the maximum host range to assist with movement controls of risk plants, surveillance activities and potential phytosanitary issues. Therefore, the determination of breeding hosts as opposed to feeding hosts is less important.

For EPG, some concern has been voiced that the gold wire attached to a test insect affects its behaviour and limits the 'reality' of the results (Prado \& Tjallingii 1999). Results differ on whether the wire may or may not affect the feeding behaviour, depending on the species, individual insects, and the skill of the EPG researcher (Sandanayaka \& Page-Weir 2009). The fact that wiring prevents an insect from escaping from an unwanted plant may result in eventual feeding on a non-host. However, the wiring constraint has negligible effect on comparative feeding parameters on different plants, whether hosts or non-hosts.

The EPG technique can provide rapid insights into the potential host range and food preferences of an insect that might not occur within the current distribution of the pest. This technique can be applied to other studies besides incursion response such as the transition to a long-term management programme of a new pest or measuring the rate of adaptation of invasive insects to existing or novel host plants in its new, expanding geographical range (Lazzarotto et al. 2011). In fact, EPG has been widely used to assist with screening resistance to pests in crop breeding programmes (Dixon et al. 1990; Webster et al. 1993; Jiang et al. 2001; Alvarez et al. 2006). Another potential use of EPG is for biosecurity preparedness. For example, studies could be conducted on close relatives of high risk invasive organisms.

The interactions among pathogens, insect vectors and their host plants have been studied extensively using EPG and this may be a wider application of EPG during biosecurity incursions. It can be used to reveal the efficiency of pathogen transmission and the minimum plant-access period required for disease transmission (Jiang et al. 2000; Moreno et al. 2005; Boquel et al. 2011; Sandanayaka 2014).

This review has summarised the inputs required, measurement, interpretation and outcomes of using the EPG technique for biosecurity incursions. Host-range outcomes can be provided within 2 to 14 days, depending on the biosecurity question and there is also potential to rapidly scale-up the volume of host-range testing for a large-scale biosecurity response at a reasonable cost.

\section{ACKNOWLEDGEMENTS}

We thank the MPI, in particular George Gill and Jo Berry, for the provision of incursion data. We also thank David Teulon (B3) and Barbara Barratt (AgR) for their valuable comments on the earlier version of this paper. This research was funded by The New Zealand Institute for Plant \& Food Research Limited as part of the Better Border Biosecurity (B3) (www.b3nz.org) research collaboration.

\section{REFERENCES}

Alvarez AE, Tjallingii WF, Garzo E, Vleeshouwers V, Dicke M, Vosman B 2006. Location of resistance factors in the leaves of potato and wild tuber-bearing Solanum species to the aphid Myzus persicae. Entomologia Experimentalis et Applicata 121: 145-157.

Backus EA, Cline AR, Ellerseick MR, Serrano MS 2007. Behaviour: Lygus hesperus (Hemiptera: Miridae) feeding on cotton: New methods and parameters for analysis of nonsequential electrical penetration graph data. Annals of the Entomological Society of America 100: 296-310.

Backus EA, Bennett WH 2009. The AC-DC Correlation Monitor: New EPG design with flexible input resistors to detect both $\mathrm{R}$ and emf components for any piercing-sucking hemipteran. Journal of Insect Physiology 55: 869-884. 
Backus EA, Hunter WB 1989. Comparison of feeding behavior of the potato leafhopper Empoasca fabae (Homoptera: Cicadellidae) on alfalfa and broad bean leaves. Environmental Entomology 18: 473-480.

Bonjour EL, Fargo WS, Webster JA, Richardson PE, Brusewitz GH 1991. Probing behavior comparisons of squash bugs (Heteroptera: Coreidae) on cucurbit hosts. Environmental Entomology 20: 143-149.

Boquel S, Ameline A, Giordanengo P 2011. Assessing aphids potato virus Y-transmission efficiency: A new approach. Journal of Virological Methods 178: 63-67. doi:10.1016/j.jviromet.2011.08.013.

Burckhardt D, Ouvrard D, Queiroz D, Percy D 2014. Psyllid host-plants (Hemiptera: Psylloidea): resolving a semantic problem. Florida Entomologist 97: 242-246.

Burnip G, Froud K 2008. Characterisation of science inputs when investigating exotic organism incursions. In: Froud KJ, Popay AI, Zydenbos SM eds. Surveillance for biosecurity: pre-border to pest management. The New Zealand Plant Protection Society, Christchurch. Pp. 143-149.

Calatayud PA, Rahbe Y, Tjallingii WF, Tertuliano M, Ru BL 1994. Electrically recorded feeding behaviour of cassava mealybug on host and non-host plants. Entomologia Experimentalis et Applicata 72: 219-232.

Cole RA 1997. Comparison of feeding behaviour of two Brassica pests Brevicoryne brassicae and Myzus persicae on wild and cultivated brassica species. Entomologia Experimentalis et Applicata 85: 135-143.

Costa Santa-Cecilia LV, Prado E, Oliveira MS 2013. Regarding to host conditioning in citrus mealybug Planococcus citri (Risso) (Hemiptera: Pseudococcidae). Revista Brasileira De Fruticultura 35: 86-92.

Dixon AGO, Bramel-Cox PJ, Reese JC 1990 Feeding behavior of biotype $\mathrm{E}$ greenbug (Homoptera: Aphididae) and its relationship to resistance in sorghum. Journal of Economic Entomology 83: 241-246.

Dungan RJ, Kelly D 2003. Effect of host-tree and environmental variables on honeydew production by scale insects (Ultracoelostoma sp.) in a high elevation Nothofagus solandri forest. New Zealand Journal of Ecology 27: 169-177.

EPG systems EU no date. Products. http://www. epgsystems.eu/epg/products

Froud KJ, Bullians MS 2010. Investigation of biosecurity risk organisms for the plant and environment domains in New Zealand for 2008 and 2009. New Zealand Plant Protection 63: 262-269.

Girma M, Wilde GE, Reese JC 1992. Russian wheat aphid (Homoptera: Aphididae) feeding behavior on host and nonhost plants. Journal of Economic Entomology 85: 395-401.

Girma M, Wilde GE, Reese JC, Backus EA 1994. Committed phloem ingestion of aphids (Homoptera: Aphididae): Difficulties in its application to host-plant resistance studies. Environmental Entomology 23: 1061-1065.

Hattori M 2001. Probing behavior of the brown planthopper, Nilaparvata lugens stal (Homoptera: delphacidae) on a non-host barnyard grass, and resistant and susceptible varieties of rice. Applied Entomology and Zoology 36: 83-89.

Holbrook FR 1980. An index of acceptability to green peach aphids for Solanum germplasm and for a suspected non-host plant. American Potato Journal 57: 1-6.

Jiang YX, De Blas C, Barrios L, Fereres A 2000. Correlation between whitefly (Homoptera: Aleyrodidae) feeding behavior and transmission of tomato yellow leaf curl virus. Annals of the Entomological Society of America 93: 573-579.

Jiang YX, Nombela G, Muñiz M 2001. Analysis by DC-EPG of the resistance to Bemisia tabaci on an Mi-tomato line. Entomologia Experimentalis et Applicata 99: 295-302.

Jin M, Baoyu H 2007. Probing behavior of the tea green leafhopper on different tea plant cultivars. Acta Ecologica Sinica 27: 3973-3982.

Lazzarotto CM, Lazzari SMN, Penteado SRC 2011. Feeding behavior of two exotic aphid species on their original hosts in a new invaded area. Neotropical Entomology 40: 316-321. 
Lei H, Van Lenteren JC, Tjallingii WF 1999. Analysis of resistance in tomato and sweet peper against the greenhouse whitefly using electrically monitored and visually observed probing and feeding behaviour. Entomologia Experimentalis et Applicata 92: 299-309.

Liu J, Takahashi S 2000. Feeding behavior of Nephotettix virescens (Homoptera: Cicadellidae) on suitable and unsuitable host plants and underlying mechanisms of host plant suitability. In: Walker GP, Backus EA eds. Principles and applications of electronic monitoring and other techniques in the study of Homopteran feeding behavior. Thomas Say Publications in Entomology. Pp. 245-260. Liu B, Yan F, Chu D, Pan H, Jiao X, Xie W, Wu Q, Wang S, Xu B, Zhou X, Zhang $Y$ 2012. Difference in feeding behaviors of two invasive whiteflies on host plants with different suitability: Implication for competitive displacement. International Journal of Biological Sciences 8: 697-706.

Madden LV, Jeger MJ, van den Bosch F 2000. A theoretical assessment of the effects of vectorvirus transmission mechanism on plant virus disease epidemics. Phytopathology 90: 576594. doi:10.1094/phyto.2000.90.6.576.

Martin NA 2008. Host plants of the potato/ tomato psyllid: a cautionary tale. The Weta 35: 12-16.

McLean DL, Kinsey MG 1964. A technique for electronically recording aphid feeding and salivation. Nature (Lond.) 202: 1358-1359.

McLean DL, Kinsey MG 1968. Probing behavior of the pea aphid, Acyrthosiphon pisum. II.Comparisons of salivation and ingestion in host and non-host plant leaves. Annals of the Entomological Society of America 61: 730739.

Ministry for Primary Industries 2010. Biosecurity Response Knowledge Base. brkb.biosecurity. govt.nz [Accessed 12 March 2017].

Ministry for Primary Industries 2011a. Manage response. http://brkb.biosecurity.govt.nz/ processes-and-procedures/manage-response [Accessed 17 March 2017].
Ministry for Primary Industries 2011b. Develop advisorygrouppapers.http://brkb.biosecurity. govt.nz/processes-and-procedures/enableresponse/advisory-groups/seek-inputfrom-technical-advisory-group/procedures/ develop-advisory-group-papers [Accessed 22 March 2017].

Ministry for Primary Industries 2011c. Prepare information for operational specifications. http://brkb.biosecurity. govt.nz/processes-and-procedures/enableresponse/operational-specifications/prepareinformation-for-operational-specifications/ process-map [Accessed 22 March 2017].

Ministry for Primary Industries 2011d. Quantify or describe costs and benefits. http://brkb.biosecurity.govt.nz/processesand-procedures/manage-response/ develop-business-case/complete-costbenefit-analysis/procedures/quantify-ordescribe-costs-and-benefits [Accessed 22 March 2017].

Ministry for Primary Industries 2012a. Obtain and assess existing information. http:// brkb.biosecurity.govt.nz/processes-andprocedures/enable-response/operationalspecifications/prepare-information-foroperational-specifications/procedures/ obtain-and-assess-existing-information [Accessed 22 March 2017].

Ministry for Primary Industries 2012b. Determine if response recommended. http://brkb.biosecurity.govt.nz/processesand-procedures/manage-response/ investigate/consider-rapid-assessmentreport/procedures/determine-if-responserecommended [Accessed 22 March 2017].

Ministry for Primary Industries 2012c. Define organism management specifications. http://brkb.biosecurity.govt.nz/processesand-procedures/en able-response/ operational-specifications/define-organismmanagement-specifications/process-map [Accessed 22 March 2017].

Ministry for Primary Industries 2012d. Psyllid, Acizzia solanicola fact-sheet. Ministry for Primary Industries fact sheet: $1 \mathrm{p}$. 
Ministry for Primary Industries 2013a. Assess the biosecurity risk. http://brkb.biosecurity. govt.nz/processes-and-procedures/manageresponse/investigate/investigate-possiblerisk-organism/procedures/assess-thebiosecurity-risk [Accessed 22 March 2017].

Ministry for Primary Industries 2013b. Define movement control specifications. http:// brkb.biosecurity.govt.nz/processes-andprocedures/enable-response/operationalspecifications/define-movement-controlspecifications/process-map [Accessed 22 March 2017].

Ministry for Primary Industries 2013c. Define surveillance options and select approach. http://brkb.biosecurity.govt. $\mathrm{nz} /$ processes-and-procedures/enableresponse/operational-specifications/definesurveillance-specifications/procedures/ discuss-surveillance-options-and-selectapproach [Accessed 22 March 2017].

Ministry for Primary Industries 2014. Rapid Assessment Recommendation Guidelines. http://brkb.biosecurity.govt.nz/processesand-procedures/manage-response/ investigate/investigate-possible-riskorganism/procedures/assess-results-ofinvestigation [Accessed 17 March 2017].

Ministry of Agriculture and Forestry 2003. Costbenefit analysis of unwanted organism or pest response options. Ministry of Agriculture and Forestry guidelines report. $18 \mathrm{p}$.

Moreno A, Palacios I, Blanc S, Fereres A 2005. Intracellular salivation is the mechanism involved in the inoculation of Cauliflower mosaic virus by its major vectors Brevicoryne brassicae and Myzus persicae. Annals of the Entomological Society of America 98: 763-769.

Nault LR 1997. Arthropod transmission of plant viruses: A new synthesis. Annals of the Entomological Society of America 90: 521-541.
Pascoe A 2016. GIA Response Guide: A guide to managing biosecurity responses under the Government Industry Agreement for Biosecurity Readiness and Response. GIA Deed Governance Group guidelines. 45 p.

Pathak PK, Saxena RC, Heinrichs EA 1982. Parafilm sachet for measuring honeydew excretion by Nilaparvata lugens (Homoptera, Delphacidae) on rice. Journal of Economic Entomology 75: 194-195.

Powell G, Tosh CR, Hardie J 2006. Host plant selection by aphids: behavioral, evolutionary, and applied perspectives. Annual Review of Entomology 51: 309-330.

Prado E, Tjallingii WF 1997. Effects of previous plant infestation on sieve element acceptance by two aphids. Entomologia Experimentalis et Applicata 82: 189-200.

Prado E, Tjallingii WF 1999. Effects of experimental stress factors on probing behaviour by aphids. Entomologia Experimentalis et Applicata 90: 289-300.

Reese J, Tjallingii WF, Van Helden M, Prado E 2000. Waveform comparisons among AC and DC electronic monitoring systems for aphid (Homoptera: Aphididae) feeding behavior. In: Walker GP, Backus EA eds. Principles and applications of electronic monitoring and other techniques in the study of Homopteran feeding behavior. Entomological Society of America, Lanham, MD. Pp. 70-101.

Sandanayaka WRM, Hale CN 2003. Electronically monitored stylet penetration pathway of woolly apple aphid, Eriosoma lanigerum (Homoptera: Aphididae), on apple (Malus domestica). New Zealand Journal of Crop and Horticultural Science 31: 107-113.

Sandanayaka WRM, Backus EA 2008. Quantitative comparison of stylet penetration behaviors of Glassy winged sharpshooter, Homalodisca vitripennis on selected hosts. Journal of Economic Entomology 101: 1183-1197. 
Sandanayaka WRM, Jia Y, Charles JG 2013. EPG technique as a tool to reveal host plant acceptance by xylem sap-feeding insects. Journal of Applied Entomology 137: 519-529.

Sandanayaka WRM, Moreno A, Tooman LK, Page-Weir NEM, Fereres A 2014. Stylet penetration activities linked to the acquisition and inoculation of Candidatus Liberibacter solanacearum by its vector tomato potato psyllid. Entomologia Experimentalis et Applicata 151: 170-181. DOI: 10.1111/ eea.12179.

Sandanayaka WRM, Page-Weir NEM 2009. Evaluation of host testing by comparing ingestion and settling behaviours. New Zealand Plant Protection 62: 191-196.

Sandanayaka WRM, Page-Weir NEM, Fereres A 2011. Real time EPG recordings of tomatopotato psyllid (Bactericera cockerelli) feeding on tomato. New Zealand Plant Protection 64: 294.

Sopow SL, Jones T, McIvor I, McLean JA, Pawson SM 2017. Potential impacts of Tuberolachnus salignus (giant willow aphid) in New Zealand and options for control. Agricultural and Forest Entomology. doi:10.1111/afe.12211.

Spiller NJ, Kimmins FM, Llewellyn M 1985. Fine structure of aphid stylet pathway and its use in host plant resistance studies. Entomologia Experimentalis et Applicata 38: 293-295.

Suckling DM, Charles JG, Kay MK, Kean JM, Burnip GM, Chhagan A, Noble A, Barrington AM 2014. Host range testing for risk assessment of a sexually dimorphic polyphagous invader, painted apple moth. Agricultural and Forest Entomology 16: 1-13. Teulon D, Workman P, Thomas K, Nielsen M 2009.

Bactericera cockerelli: incursion, dispersal and current distribution on vegetable crops in New Zealand. New Zealand Plant Protection 62: 136-144.
Tjallingii WF 1976. A preliminary study of host selection and acceptance behaviour in the cabbage aphis, Brevicoryne brassicae L. Symposia Biologica Hungarica 16: 283-285.

Tjallingii WF 1978. Electronic recording of penetration behaviour by aphids. Entomologia Experimentalis et Applicata 24: 721-730.

Tjallingii WF 1995. Aphid-plant interactions: What goes on in the depths of the tissues? Proceedings of Experimental and Applied Entomology 6: 163-169.

Tjallingii WF, Hogen Esch TH 1993. Fine stucture of aphid stylet routes in plant tissues in correlation with EPG signals. Physiological Entomology 18: 317-328.

Trębicki P, Tjallingii WF, Harding RM, Rodoni BC, Powell KS 2012. EPG monitoring of the probing behaviour of the common brown leafhopper Orosius orientalis on artificial diet and selected host plants. Arthropod-Plant Interactions 6: 405-415.

Ullman DE, McLean DL 1988. The probing behavior of the summer-form pear psylla. Entomologia Experimentalis et Applicata 47: 115-125.

Webster JA, Porter DR, Baker CA, Mornhinweg DW 1993. Resistance to Russian wheat aphid (Homoptera: Aphididae) in barley: effects on aphid feeding. Journal of Economic Entomology 86: 1603-1608.

Withers TM, Potter KJ, Berndt LA, Forgie SA, Paynter QE, Kriticos DJ 2011. Risk posed by the invasive defoliator Uraba lugens to New Zealand native flora. Agricultural and Forest Entomology 13: 99-110.

Zúñiga GE, Varanda EM, Corcuera LJ 1988. Effect of gramine on the feeding behavior of the aphids Schizaphis graminum and Rhopalosiphum padi. Entomologia Experimentalis et Applicata 47: 161-165. 